\title{
Guest Editorial:Free Trade Agreements, Logistics Hubs and the China-Korea Connection
}

\author{
Peter J. Rimmer
}

This issue focuses upon the nature of free trade agreements, the characteristics of logistics hubs and the strength of the China-Korea economic connection. Exploration of these topics is designed to fulfil the mission of the Jungseok Research Institute (JRI) to provide high quality information on international logistics, trade and economic cooperation. The six papers and three research reports in this issue are divided equally between these three themes.

\section{Free Trade Agreements}

Since the Second World War the global trading system, buttressed first by the General Agreement on Tariffs and Trade (GATT) and then by the World Trade Organization (WTO), has provided the base for East Asia's export-oriented development and subsequent economic success. Unlike Europe and North America, there was little apparent interest in East Asia on regional free trade. Since the mid-1990s, however, there has been a marked policy shift among East Asian countries towards bilateral free trade agreements between each other or with countries outside the region. The ramifications of this policy shift are the focus of the three papers on international trade.

Inkyo Cheong from Inha University considers Korea's policy on bilateral free trade agreements. The main thrust of his argument is that Korea should practice negotiating agreements with smaller countries before advancing to an agreement with Japan, a more significant trading partner, though ranking well below China and the United States. Increasing opposition from Korean industries, labor unions, non-government organizations and academia to the Korea-Japan free trade agreement during 2004 are noted by Cheong, before he suggests that their negative perceptions and concerns are, to some extent, overstated because of an inaccurate estimation of the probable economic effects. Although opposition is likely to be sustained to a free trade agreement with Japan, the resistance appears to run counter to Korea's policy of becoming established as a business hub for northeast Asia.

Keuk-Je Sung from Kyung Hee University takes another direction on the free trade issue by focusing on the rationale for the participation of developing countries in trade negotiations. As the general public in these countries seem unconvinced by the comparative advantage argument, developed originally by the British economist David Ricardo (1772-1823), alternative arguments need to be developed other than that free trade generates more trade by offering consumers wider choices and allowing producers to concentrate on their specialty. According to Sung, regulatory reform under the General Agreement on Trade in Services (GATS) could be one of these alternative arguments and he proceeds to develop this notion with reference to Korea. In particular, he underlines that without the proper development of the service sector in Korea the agricultural and 
manufacturing sectors cannot grow. However, it is still a moot point as to whether this interesting argument will be sufficiently persuasive for the general public in developing countries to support their governments' involvement in the Doha Development Agenda negotiations in the World Trade Organization.

Jung Taik Hyun and Jin Young Hong from Inha University examine the history, characteristics and problems inherent in the range of bilateral free trade agreements between countries within East Asia and those involving a country outside the region. While academics suggest that these bilateral agreements will generate positive welfare benefits and acquiesce in government policy on these matters, Hyun and Hong offer a much-needed critical assessment by pointing to economic modelling defects and the distinct possibilities of inefficient resource allocation and very limited social returns. There is a real prospect that governments will be diverted by bilateral free trade agreements and a multilateral-cum-regional strategy and resile from economic reforms and the pursuit of the wider benefits still to be derived from a multilateral trade approach.

\section{Logistics Hubs}

The three papers on logistics stem from nineteen papers presented at the Incheon International Logistics Seminar 13-14 October 2004. The overall theme of the Seminar was centred on Strategies to Develop Incheon as a Logistics Hub in Northeast Asia.

Michael Bomba and Robert Harrison from the University of Texas at Austin provide a link between the preceding discussions of international trade and logistics hubs by examining changing shipping patterns between Asian countries in the Asian-Pacific Economic Cooperation (APEC) agreement and the United States, with an emphasis on the Republic of Korea's strategy to become a business hub for Northeast Asia. Interest is focused upon changing ship size, shipping routes and load centers in the Gulf of Mexico and relating them intermodal coastal shipping services in Korea The Gulf' s feeder services are particularly relevant to developing the seaport component of the proposed Incheon Pentaport - the five-ports-in-one project - with the airport, business port, technoport and leisure port as the other four elements. Lessons drawn from the pros and cons of the Osprey Line' s experience in using container-on barge in the Gulf are pertinent to the development of Short Sea Shipping (SSS) linking Incheon with other ports in Korea to obviate the need for land-based container movements, and in developing transhipment trade from the port in question with China and Japan.

Jaap de Wit from the University of Amsterdam complements the Bomba and Harrison contribution by shifting attention from the seaport to the airport and relating the lessons derived from the development strategy of Schiphol Airport in his home city to Incheon Airport's future roles. After reviewing the air cargo market and pinpointing the dynamism inherent in the intra-Asian market compared with Europe, de Wit highlights the importance of geographic location, runway capacity and the extensive airline networks possessed by a home-based carrier as the base factors for an air cargo hub. The 
management of Schiphol is going beyond being an airport cargo hub by pursuing a trilevel strategy to become simultaneously an air transport hub, multimodal hub and logistics hub. Traffic rights and capacity problems elsewhere in the region assist the development of an air transport hub (e.g. Incheon as a hub for the Japanese market). A multimodal hub is dependent upon interconnected road, rail and SSS connections because they are critical part of door-to-door transport chains. A regional logistics hub is facilitated by the proximity of long and short-haul networks and value-added services. These distinctions are important in any strategy being devised to develop Incheon International Airport as an airport city.

Peter Rimmer from the Australian National University provides a connection with the preceding papers on seaports and airports in his discussion on how to market Incheon as a Pentaport. His paper highlights that there is considerable attraction in marketing cities as a product, which stems from the interest in competitive cities and intelligent cities generated by the new economic geography theorists. Both of these types of cities are incorporated in initiatives being pursued by Incheon Metropolitan City with a twin focus on logistics to boost localized economic systems and on Songdo intelligent city to offer the prospects of generating urban wealth from knowledge-based activities. As studies on place marketing in Asia center on Seoul rather than Incheon, the paper suggests the Capital Region as a whole should be considered in positioning the city-region in the new global geography. However, city-region boosters should beware that firms, not cities, compete and the emphasis on marketing Seoul-Incheon should be both local and global. As life, including face-to-face contact, takes place over varying distances from the local to the global, the challenge is to explain how the local milieu can tap into sources of specialized knowledge to develop and maintain international competitiveness.

\section{Research Notes: Economic Relations Between China and Korea}

A new feature in this issue is the introduction of Research Notes, which are contributions that are not reviewed but meet the Jungseok Research Institute's aim of providing high quality information on economic cooperation. On this occasion, the Research Notes stem from papers given at the Korea-China Economic Growth Seminar on 25 November 2004. The theme of the Seminar was "Korea-China: Economic Growth and Valuation" and together the three reports provide a succinct review of economic relations between China and Korea. All three authors are members of the Institute of Economics of the Chinese Academy of Social Sciences (CASS) in Beijing.

In the first report Xiaohong Zhang examines key features in the development of South Korea's relatively profitable direct investment in China since 1992, spurred by the country's low-price production factors, market potential, stable investment environment and quiescent labor force. These include the late start and rapid rise in investments, relatively small average size of investments, acceleration of localization of the workforce, diversified range of industrial activities and widening spread of geographical locations. The second report by Shucheng Liu studies the latest phase of China's economic cycle. 
Specifically, he examines how macroeconomic regulation is being used currently to moderately contract growth and boost international trade and investment in an economy where a per capita gross domestic product of US $\$ 1,000$ guarantees further growth, but where an upsurge in economic growth is pressing 10 per cent and creating a supply crisis in the coal, power, fuel and transport sectors. Finally, the third report by Cheng Wang explores the proposition, that the confrontational relationship between employers and trade unions that characterizes the traditional employment market in China and Korea, could be overcome through development of a core employment market. The market would be based upon expanding innovation with entrepreneurship by employing modern information and communications technology and human resources management.

Collectively, the papers and reports stemming from the various activities sponsored by the Jungseok Research Institute contribute towards the provision of a solid research base. This base will enable researchers to respond to rapidly changing circumstances and to contribute towards Korea's advancement towards a knowledge-based society. 